\title{
Performance of Cassava Cultivars in an Oxisol in Northwestern Puerto Rico ${ }^{1}$
}

\begin{abstract}
J. Badillo-Feliciano ${ }^{2}$
ABSTRACT

Fifty-five cassava cultivars (Manihot esculenta, Crantz) were evaluated for 3 consecutive years in a Coto clay (Oxisol) in northwestern Puerto Rico. The highest yielders, averaged over 3 years, were PI 12902, Jamaica 18, PI 9570 and $\mathrm{PI} 12003$ with $34,345,29,906,26,845$ and $24,684 \mathrm{~kg} / \mathrm{ha}$, respectively. The organoleptic evaluation reveals that all but PI 12903 were found to be acceptable. The hydrocyanic acid content among cultivars was below the moderately toxic levels, $(50 \mathrm{p} / \mathrm{m})$. These results are in line with previous work conducted in east central Puerto Rico.
\end{abstract}

\section{INTRODUCTION}

Cassava (Manihot esculenta Crantz) is a perennial vegetatively propagated shrub mainly grown for its edible roots. The fresh roots of cassava contain 30 to $40 \%$ dry matter, approximately $85 \%$ of which is starch. It is a staple in most of the developing countries and ranks fourth as a dietary source of calories in the tropics (1) producing $493 \mathrm{Kcal} / \mathrm{lb}$ (4). It is useful as livestock feed $(1,6,8)$.

In the past decade, local production declined; therefore, the demand has to be covered with imports from the Dominican Republic. During 1979-80 local production (3) was reported as $12,733 \mathrm{cwt}$ with a value of $\$ 241,819$, while imports were reported as 5,917 cwt. These figures obviously show that demand exceeds local production and suggest the feasibility of increasing the area planted of this crop. Besides, it is well known that cassava has the ability to survive with low fertilizer inputs and under water stress. It is also highly disease- and pest-resistant.

In order to increase our local production a program for testing local selections and introductions has been started. Fifty-five cultivars from the cassava collection were tested for 3 consecutive years. This paper presents the results obtained from field trials in which cassava cultivars were tested as to yielding ability in an Oxisol in northwestern Puerto Rico, and their acceptance by a tasting panel.

\section{MATERIALS AND METHODS}

Selections were made from a collection of introductions and local cassava cultivars that seemed to be well adapted to local conditions. Three experiments were conducted at the Isabela Research and Devel-

\footnotetext{
${ }^{1}$ Manuscript submitted to Editorial Board October 3, 1983.

${ }^{2}$ Agronomist, Agricultural Experiment Station, Mayagüez Campus, University of Puerto Rico, Rio Piedras, P.R.
} 
opment Center in northwestern Puerto Rico, $128 \mathrm{~m}$ above sea level, lat. $18^{\circ} 28^{\prime} \mathrm{N}$, where the mean annual minimum and maximum air temperature are 18.9 and $29.4^{\circ} \mathrm{C}$, respectively. Mean annual rainfall is $1685 \mathrm{~mm}$. The soil is classified as Coto, a Tropeptic Haplorthox; clayey, kaolinitic, isohyperthermic, with a $\mathrm{pH}$ of 5.2 (5).

The experiments were planted in March of each respective year and the roots were harvested about 12 months after planting. The experiments followed randomized complete block designs with three replications. The plots were $4.8 \mathrm{~m} \times 4.8 \mathrm{~m}$ with $1.2 \mathrm{~m}$ alleys between them. Each plot consisted of four rows $1.2 \mathrm{~m}$ apart with plants spaced $1.2 \mathrm{~m}$ within the row (6) for a total of 16 plants per treatment per replicate. The four inner plants were harvested for yield data collection. The planting material was derived from mature plant stem cuttings with five or six nodes. The crop received a 6-6-12 fertilizer in a split application at the rate of $800 \mathrm{~kg} / \mathrm{ha}$. The first half ( $56 \mathrm{~g} / \mathrm{plant}$ ) was applied 1 month after planting; the remainder, 2 months later. Supplemental irrigation was applied as needed. The cassava plants were free from insects and diseases throughout the growing season; thus no control measures were necessary. Evaluation of the cultivars was not solely on the basis of yield; due consideration was given to other factors such as growth habit, ability to smother weeds, HCN content and acceptance by tasters. The sensory evaluation was based on a 6-point hedonic scale (7) ranging from 6, "like very much" to 1 , "dislike." The cooked samples were evaluated for appearance, flavor, texture and overall acceptability. Some high yielding cultivars were not acceptable because of undesirable characteristics. Because of the large and variable number of cultivars included at the beginning of the experiments data from only the outstanding cultivars are presented in this paper. Rank, based on yields, plus agronomic considerations and acceptance by a tasting panel were determinant factors in the final selection of the outstanding cultivars.

\section{RESULTS AND DISCUSSION}

Table 1 shows data on the performance of the 12 outstanding cassava cultivars for three consecutive crops. There were significant differences in yield of edible roots among cultivars. In the 1980-81 trial, 55 cassava cultivars were tested. The cultivars that yielded over $22,000 \mathrm{~kg} / \mathrm{ha}$ were kept for further trials. In this first trial, cvs. PI 12902, Jamaica 18, PI 9570 and PI 12903 yielded 39,921,31,104,28,100 and 23,220 kg/ha of edible roots, respectively. Although there were no significant differences among the four cultivars, the yields are in line with values reported previously by Ramírez et al. (8) and surpassed the averages reported for Africa (7t/ha) and South America (14t/ha). Also, the yield values are 
in agreement with the goal of $34 \mathrm{t} /$ ha suggested in the Agricultural Experiment Station guide for the production of starchy food crops (2).

In the 1981-82 trial, 30 cultivars were tested. The yield ranged from a low of 4,628 to a high of $28,887 \mathrm{~kg} / \mathrm{ha}$. Cvs. PI 12902, Jamaica 18, PI 9570, and PI 12903, however, ranked 4th, 3rd, 7th, and 8th with yields of $27,794,28,100,25,252$ and $25,175 \mathrm{~kg} / \mathrm{ha}$, respectively. Although the yields were lower than those obtained in the previous year, these cultivars have been consistently good yielders.

In the 1982-83 trial, the 12 outstanding cultivars from previous trials were compared. Cultivars PI 12902, Jamaica 18, PI 9570 and PI 12903 yielded $35,322,30,515,27,184$ and $25,658 \mathrm{~kg} / \mathrm{ha}$, respectively. These four

TABLE 1.-Mean yields of the 12 outstanding cassava cultivars planted during three consecutive years at Isabela, Puerto Rico

\begin{tabular}{lrrrrrr}
\hline \multirow{2}{*}{ Cultivar } & \multicolumn{2}{c}{$1980-81$} & \multicolumn{2}{c}{$1981-82$} & \multicolumn{2}{c}{$1982-83$} \\
\cline { 2 - 7 } & $\mathrm{kg} / \mathrm{ha}$ & Rank & $\mathrm{kg} / \mathrm{ha}$ & Rank & $\mathrm{kg} / \mathrm{ha}$ & Rank \\
\hline PI 9608 & 25430 & 9 & 28888 & 1 & 24438 & 7 \\
PI 1290 & 26373 & 10 & 28507 & 2 & 25023 & 6 \\
Jamaica 18 & 31104 & 4 & 28100 & 3 & 30515 & 2 \\
PI 12902 & 39921 & 1 & 27794 & 4 & 35322 & 1 \\
Brava & 29756 & 5 & 27718 & 5 & 25480 & 5 \\
Mc22 & 23980 & 24 & 27489 & 6 & 14546 & 12 \\
PI 9570 & 28100 & 7 & 25252 & 7 & 27184 & 3 \\
PI 12903 & 23220 & 25 & 25175 & 8 & 25658 & 4 \\
Brazil & 24034 & 11 & 23344 & 9 & 19530 & 10 \\
Pana & 24644 & 10 & 23217 & 10 & 19886 & 9 \\
PI 9569 & 25865 & 13 & 23065 & 11 & 22403 & 8 \\
Jordan & 28204 & 6 & 22963 & 12 & 18769 & 11 \\
$\quad$ Cultivars & 55 & & 30 & & 12 & \\
LSD .01 & 24799 & & 18842 & & 24805 & \\
\multicolumn{1}{c}{05} & 19462 & & 14306 & & 18243 & \\
\hline
\end{tabular}

cultivars were consistently superior in yield throughout the 3 -year testing period. There were no significant differences in yield among them; however, cv. PI 12902 yielded significantly more than the other 11 cultivars tested.

The highest yielding cultivars in terms of total number of edible roots, were Brazil with 71,759/ha; PI 12902, with 63,350; and Jamaica 18, with 60,547 roots (table 2). Cultivars 12902, Jamaica 18, PI 9570, and PI 12903 did not differ statistically as to number of total or marketable roots. These four cultivars yielded $81,70,76$, and $76 \%$ of marketable roots, respectively. These values are in line with those reported previously by Ramirez et al. (8).

The HCN content (table 3 ) of the 12 tested cultivars ranged from 0 to 
TABLE 2.-Mean number of roots per cv. per hectare, 1982-83 crop

\begin{tabular}{llc}
\hline \multirow{2}{*}{ Cultivar } & \multicolumn{2}{c}{ Roots per hectare } \\
\cline { 2 - 3 } & Total number & Percent marketable \\
\hline PI 12902 & $63350 \mathrm{ab}^{1}$ & $81.10 \mathrm{ab}$ \\
Jamaica 18 & $60547 \mathrm{abcd}$ & $71.52 \mathrm{ab}$ \\
PI 9570 & $48213 \mathrm{bcd}$ & $75.41 \mathrm{ab}$ \\
PI 12903 & $52138 \mathrm{bcd}$ & $77.02 \mathrm{ab}$ \\
Brava & $61668 \mathrm{abc}$ & $66.51 \mathrm{ab}$ \\
PI 12900 & $44289 \mathrm{~cd}$ & $71.80 \mathrm{ab}$ \\
PI 9608 & $56062 \mathrm{abcd}$ & $75.10 \mathrm{ab}$ \\
PI 9569 & $43728 \mathrm{~d}$ & $82.19 \mathrm{a}$ \\
Pana & $45410 \mathrm{~cd}$ & $77.65 \mathrm{ab}$ \\
Brazil & $71759 \mathrm{a}$ & $59.64 \mathrm{bc}$ \\
Jordan & $42046 \mathrm{~d}$ & $66.14 \mathrm{ab}$ \\
Mc22 & $49895 \mathrm{bcd}$ & $55.65 \mathrm{c}$ \\
\hline
\end{tabular}

${ }^{1}$ Means followed by one or more letters in common do not differ significantly at $\mathrm{P}=05$, according to Duncan's multiple range test.

TABLE 3.-Hydrocyanic acid (HCN) content and sensory evaluation of 12 cassava cus

\begin{tabular}{lrcccc}
\hline & & \multicolumn{4}{c}{ Mean values $^{2}$} \\
\cline { 3 - 6 } Cultivar & $\mathrm{HCN}^{1}$ & $\begin{array}{c}\text { Appearance } \\
\text { cooked }\end{array}$ & Flavor & Texture & $\begin{array}{c}\text { Overall } \\
\text { acceptability }\end{array}$ \\
\hline & $\mathrm{p} / \mathrm{m}$ & & 3.41 & 2.74 & 2.85 \\
PI $^{3}$ 6569 & 10 & 3.65 & 3.87 & 3.76 & 3.85 \\
PI 9570 & 0 & 3.50 & 2.62 & 4.16 & 2.71 \\
PI 9608 & 0 & 4.25 & 3.55 & 3.41 & 3.23 \\
Brazil & 0 & 4.37 & 1.35 & 2.81 & 1.33 \\
Brava & 20 & 3.67 & 4.87 & 4.65 & 4.85 \\
PI 12900 & 0 & 4.65 & 2.50 & 3.65 & 2.58 \\
PI 12903 & 10 & 4.92 & 4.40 & 4.16 & 4.27 \\
Pana & 0 & 4.36 & 4.84 & 4.49 & 4.94 \\
Mc22 & 0 & 4.25 & 3.80 & 4.53 & 4.01 \\
Jordan & 10 & 4.89 & 4.25 & 4.11 & 4.03 \\
PI 12902 & 10 & 4.87 & 4.05 & 3.41 & 3.53 \\
Jamaica 18 & 0 & 4.77 & & \\
\hline
\end{tabular}

${ }^{1}$ Values below $50 \mathrm{mg}, \mathrm{HCN} / \mathrm{kg}$ fresh peeled root are considered safe.

${ }^{2} 6$-point hedonic scale (6-liked very much; 5-liked; 4-liked moderately; 3-neither liked or disliked; 2-disliked a bit; 1 -disliked.

${ }^{3}$ University of Puerto Rico, Agricultural Experiment Station, plant introduction number.

$20 \mathrm{p} / \mathrm{m}$; i.e., they are below the moderately toxic level considered to range between 50 to $100 \mathrm{p} / \mathrm{m}$, in fresh, peeled roots (7).

Table 3 also presents data on the sensory evaluation of the 12 cassava cultivars. All cultivars had acceptable appearance after being cooked. Cultivars PI 12903, Jordan, PI 12903 and Jamaica 18 were among the four most attractive ones. Cultivars PI 12902 and Jamaica 18 were rated 
TABLE 4.-Description of 12 cassava cultivars

\begin{tabular}{|c|c|c|c|c|c|c|c|c|}
\hline \multirow{2}{*}{ Cultivar } & \multirow{2}{*}{ Stem color } & \multicolumn{2}{|c|}{ Leaf } & \multicolumn{2}{|c|}{ Root mean ${ }^{1}$} & \multicolumn{2}{|c|}{ Color } & \multirow{2}{*}{ Pulp } \\
\hline & & Color & \# Jobules & Length & Width & Exodermis & Endodermis & \\
\hline 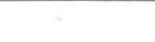 & & & & $\mathrm{cm}$. & $\mathrm{cm}$. & & & \\
\hline PI 9608 & Dark green & Green & 7 & 38.6 & 6.50 & Dark brown & White & White \\
\hline PI 12900 & Reddish brown & Dark green & 5 & 24.2 & 6.36 & Yellowish brown & White & White \\
\hline Jamaica 18 & Brown & Green & 5 & 36.0 & 5.04 & Brown & Brown & White \\
\hline PI $12902^{2}$ & Reddish brown & Light green & 5 & 40.2 & 6.30 & Brown & White & White \\
\hline Brava & Brown & Dark brown & 5 & 33.6 & 7.36 & Brown & Cream & White \\
\hline Mc22 & Cream & Dark green & 5 & 39.0 & 5.60 & Light brown & White & White \\
\hline PI 9570 & Light gray & Green & 5 & 43.4 & 5.22 & Light brown & Cream & Cream \\
\hline PI $12903^{3}$ & Cream & Dark green & 5 & 27.5 & 6.78 & Cream & White & White \\
\hline Brazil & Reddish brown & Dark green & 7 & 35.6 & 5.62 & Brown & White & Cream \\
\hline Pana & Cream & Dark green & 7 & 28.8 & 4.68 & Brown & Violet & White \\
\hline PI 9569 & Cream & Green & 5 & 51.4 & 6.54 & Light brown & Cream & Yellow \\
\hline Jordan & Cream & Dark green & 5 & 33.2 & 4.86 & Light brown & Cream & Yellow \\
\hline
\end{tabular}

${ }^{1}$ Average of 10 roots.

${ }^{2} \mathrm{cv}$. IAC Mantequeira.

${ }^{3}$ cv. SRT 59B- Sta. Catarina. 
by the panel as "liked moderately" for flavor; however, cv. PI 12903 had a rating of 2.50 in the hedonic scale of 1 to 6 , where 6 is "liked very much." As for texture, cvs. PI 12902, Jamaica 18, PI 12903, and PI 9570 all were rated above 3.41 . All these cultivars were generally acceptable except cv. PI 12903. Cv. Brava had the lowest overall acceptability rate.

A striking feature of $\mathrm{cv}$. PI 12900 is its consistent performance as a high yielder throughout the 3 -year period. It rated second in overall acceptability with a value of 4.85 , thus coming very close to being "liked." $\mathrm{Cv}$. Jordan, although with acceptable flavor and appearance after cooking, continues declining in yield throughout the years.

The description of 12 cultivars in table 4 may help in their identification. There are differences, as expected, in stem and leaf color and in number of lobules/leaf. Cv PI 12903 has a short $(27.5 \mathrm{~cm})$ but thick $(6.78$ $\mathrm{cm})$ root, whereas PI 9570 has a very long $(43.4 \mathrm{~cm})$ but thin $(5.22 \mathrm{~cm})$ root. There are also differences in peel color which might or might not match with the pulp color. Cultivars Jamaica 18 and PI 12902 are brown externally but have white pulp; cv. PI 9570 has a light brown peel and a cream colored pulp.

According to the data on yield, overall acceptability, percentage of marketable roots and root description, cvs. PI 12902, Jamaica 18, and PI 9570 are outstanding. These cultivars, except PI 9570, were also outstanding on a previous trial conducted by Ramirez et al. (8) in the Corozal area. Cultivars PI 12903 and Brava are consistently high yielders, but their acceptability for the fresh market is low. However, they may be promising for livestock feeding and for industrial purposes.

\section{RESUMEN}

Se hicieron tres experimentos de campo en un suelo Coto arcilloso (Oxisol) en Isabela, para evaluar cultivares de yuca de una colección de 55 especímenes. Un grupo de catadores comparó las cultivares para rendimiento y aceptación. Las de baja producción y de características agronómicas indeseables o de poca aceptación se eliminaron. Por tal razón, el primer año se compararon 55 cultivares; el segundo año, 30; y el tercero, 12. Se utilizó un diseño experimental de bloques distribuidos al azar con tres repeticiones.

Las cultivares PI 12902, Jamaica 18, PI 9570 y PI 12900 fueron las de mejor rendimiento los 3 años, además de ser las más aceptables para los catadores. Los rendimientos medios están sobre $26,600 \mathrm{~kg} / \mathrm{ha}$, los que se consideran aceptables. Las cultivares Brava y PI 12903, aunque de altos rendimientos, no se juzgaron aceptables como producto en fresco, pero parecen tener potencial para usos industriales o como alimento para animales. 
Luego de tomar en consideración los rendimientos, el porcentaje de raíces comerciales y la estimación de los catadores, las cv. PI 12902, Jamaica 18 y PI 9570 parecen ser las más prometedoras para consumo en fresco y las cv. PI 12903 y Brava posiblemente para otros usos.

\section{LITERATURE CITED}

1. Cock, J. H., 1982. Cassava: A Basic Energy Source in the Tropics, Science, 218: 75562.

2. Conjunto Tecnológico para la Producción de Cosechas Farináceas, 1976. Publ. 101, Esta. Exp. Agric. Univ. P.R.

3. Facts and Figures on Puerto Rico's Agriculture 1979-80, Commonwealth of Puerto Rico, Dep. Agric., Office of Agricultural Statistics, Santurce, P.R.

4. Guerney, J. M., 1976. Nutritional considerations regarding staples, Paper presented at the 12th Annu. Meet. Caribb. Food Crops Soc., Kingston, Jamaica.

5. Lugo-López, M. A. and Rivera, L. H., 1977. Updated Taxonomic Classification of the Soils of Puerto Rico, Univ. P.R. Agric. Exp. Stn. Bull. 258.

6. Montaldo, A., 1972. Cultivo de Raices y Tubérculos Tropicales, Inst. Int. Cienc. Agric., OEA, Lima, Perú.

7. Pergam, D. R. and Pilgrin, F. J., 1957. Hedonic scale method for measuring food preferences, Food Technol. 11 (9): Insert 9.

8. Ramírez, O. D., Green, J. J., and Caloni, I. B., 1983. Evaluation and acceptability of cassava cultivars, J. Agric. Univ. P.R. 67 (1): 16-21. 